\title{
Aboriginality and Impersonality: Three Australian Indigenous Administrative Memoirs
}

\section{Tim Rowse}

The Indigenous public servant is a relatively recent phenomenon - a product of the maturing of the programs of assimilation and the inception of the programs of self-determination. That the Indigenous administrative memoir is recent follows from this, but it is also relevant to point out that the genre Indigenous autobiography is itself not yet fifty years old. In this essay, I will tell you about three Indigenous autobiographies in which the authors (all male) have produced an account of themselves partly by reflecting on their times as a public servant. In each case, the theme 'impersonality' is prominent, but each time in a different way.

\section{Charles Perkins}

Charles Perkins wrote A Bastard Like Me (1975) early in his career as a public servant. Perkins recalled 'as a compromise' his accepting a research officer position in the Office of Aboriginal Affairs in 1968. He would forsake political activism in order to realise 'the possibilities in the position ... I knew that I was, in a way, being bought off', but he welcomed the 'administrative experience' and the opportunity for influence (1975: 109). The first six months in the job he recalled as 'degrading': 'People set out deliberately to show me where I belonged (or should belong), and to make me feel completely an inferior person and nonentity in Aboriginal affairs' (1975: 109).

Before taking up the job, however, Perkins visited many countries in a three month trip abroad. He came to dislike many Australian diplomatic officials. Their duties included helping him, but 'they regarded me as inferior in intelligence' and he inferred that they looked forward to his moving on. 'I came to the conclusion that most diplomats are professional liars, two-faced' and too mindful of their own convenience to be effective servants of the Australian public. 'I feel they live in a world of their own and regard others as bloody intruders' (1975: 122). He found the Washington Embassy officials especially obstructive. One of them, he recalled, accused him of 'jumping on the racial bandwagon' (1975: 126). By the time he and his wife reached Moscow (travelling West to East) Perkins had come to think that 'perhaps my reputation at other Australian Embassies had preceded me and they were fearful that I might embarrass them' (1975: 138). Upon returning to Australia, he reported his 
displeasure to a debriefing attended by Paul Hasluck and by senior officials of External Affairs. The notes on that meeting are presumably in the National Archives and would make interesting reading.

Perkins commenced work with the Office of Aboriginal Affairs in March 1969. Although his position was junior, he was a figure of great interest (whether positive or negative) to senior political figures, as his book attests with its many brief anecdotes about conversations with people such as Gorton, Anthony, Bryant and Hasluck. It must have been difficult to reconcile the roles of national political figure and junior public servant. I suggest that we understand this specific difficulty as overlaying and exacerbating the trials that induction into the classical traditions of the public service imposes upon any person who is politically opinionated and politically active. Perkins writes - not wholly in criticism - that 'the bureaucracy swallowed me up' (1975: 157). He had to learn what he calls 'paper warfare': writing and responding to writing, and doing both within a large, opaque hierarchical establishment in which he was but one junior functionary.

As well, Perkins found the social environment of his work place cold, unfriendly and abounding in insults to his pride that were no less hurtful for being, often, unintended. 'I had to cover it up by saying nothing and swallowing my pride' (1975: 158). Though he conceded that he had always found it difficult to make friends, he also attributed his social difficulties in Canberra to the typical impersonal nature of the public service'. 'Impersonality', he then remarks, is 'one of the tragedies in the public service' (1975: 159). Perkins suggested a way to overcome this systemic disaffection.

It would seem a good thing that public servants work elsewhere every ten years to meet the general pubic on a different level and to humanize them. It would do them personally a lot of good, their families, their work and the general public. Perhaps if superannuation benefits were extended to the public service and the private sector alike, people could move more freely. A lot would move out of the public service and make a great contribution to private industry if this were done (159).

The Department of Aboriginal Affairs could be improved by making it a statutory authority allowed to recruit Aborigines to senior positions, he suggested (1975: 194). 'There are just too many whites in Aboriginal Affairs - unfortunately the good ones leave in disgust or disillusionment or get depressed' (1975: 196).

By the time he penned these thoughts, the Whitlam Government had both raised the possibility of administering Aboriginal affairs in new ways and revealed to Perkins the inflexibility of the public service culture and of the Council for Aboriginal Affairs. As well, the Australian press continued to be, in his view, 'anti-Aboriginal' (1975: 182). Perkins thought that he had failed to live up to the expectations that other Aborigines had of him. Early in the Whitlam 
Government, he was promoted from clerk class 7 (third division) to Assistant Secretary (second division [now senior executive service]). He had not internalised the disciplines expected of a public servant. It was while on leave from that position that he wrote in $A$ Bastard Like Me of his disappointment that he had been suspended in 1974 for making statements that the Government found embarrassing. 'I knew that I was breaking public service regulations but the issues were too vital and the regulations therefore just had to go' (1975: 196).

Perkins was not only at odds with the regulations about confidentiality of advice, he also thought that the department was hamstrung by its concern for financial administration. It did not allow Aborigines to make such mistakes as 'some mishandling of funds or money seemingly wasted on special projects ... The well-worn myth is that Aborigines are irresponsible with money. This is propaganda to deny Aborigines the right to make their own decisions' (1975: 178). If Aboriginal people make mistakes and 'suffer,' then they will learn to be independent and confident, Perkins argued. (However, he did not concede that in the regime of strict financial administration about which he complained the Department had a way both to define 'mistakes' and to impose 'suffering'.)

\section{Gordon Matthews}

When Gordon Matthews, author of An Australian Son, joined the Department of Foreign Affairs, he believed that he was of Aboriginal descent. He had been adopted as a baby and did not know who his natural father was. While at school (at Scotch College, Melbourne) he had been subject to racist teasing and, in this cruel way, offered the identities 'Abo' and 'Boong'. While resenting such teasing, he considered it possible that he was of Aboriginal descent. As an undergraduate at the University of Tasmania, he was persuaded by an advocate of Aboriginal education that he probably had 'Aboriginal blood' and that he was entitled to a Commonwealth study grant. He was attracted to this possibility, for the certainty it gave him about his identity, and because he felt that 'I had suffered for my colour' (1996: 76). His adoptive parents and the Commonwealth accepted his decision.

He subsequently found out that his natural father was not Aboriginal but Sri Lankan. Between the act of identification and this discovery, Gordon learnt to be Aboriginal. One lesson came directly from the Australian public service. Gordon applied for a position in Foreign Affairs. In the interview (which took place in the late 1970s or early 1980s), he was told that his Aboriginal background was one of the qualities that made him attractive to the Commonwealth. Once in the job, his contact with other Indigenous public servants gave him the sense that, for the first time in his life, he was 'participating actively in Aboriginal Australia' (1996: 89). As well, he was assigned to duties in the Department's promotion of awareness of Aboriginal culture and in its recruitment of Indigenous staff. The Commonwealth's multi-faceted promotion of Aboriginality was a 
nurturing context for Gordon, making it unimportant, for a while, that he had never proven to his own satisfaction that his father had been Aboriginal. However, that question never completely left his mind, and he undertook a long search for the identity and whereabouts of his natural parents. Most of the second half of his book is about how he and his natural parents and siblings came to terms with one another, once he presented himself to them.

Among the anxieties provoked in Gordon by his discovery that his father was not Aboriginal was a certain insecurity about his status in the Department of Foreign Affairs. The Bicentennial was looming, and in that politically sensitive context it was likely that Gordon's Aboriginality would become an even more salient part of his work for the Australian government. How could he tell his superiors that he was not, after all, an Aboriginal man? In the event, Gordon's boss took the revelation well and decided that, apart from altering his personal file, the Department need not make his change of ethnic status a public matter. His Indigenous public service colleagues sympathised with the personal ordeal of 'de-Aboriginalisation', and they treated him the same as before. Indeed, 'indigenous officers in the Department insisted I continue to participate in the informal group we had established to discuss issues relevant to indigenous staff' (1996: 210). One 'senior Aboriginal leader' told him that he was still Aboriginal because his life had been shaped by the assumption that he was. As well, as Gordon writes, 'I had experienced first-hand what it felt like to grow up Aboriginal in mainstream Australia' (1996: 211).

To grow up in 'mainstream Australia' in Gordon's times (1960s and 1970s) meant being positioned both negatively in popular culture and positively in official culture. Not only was he taunted with epithets such as 'boong' and 'Abo' at Scotch College, but he was also favoured by state practices of representing 'Aboriginal heritage' as part of Australia's nationhood. And the positive valuation of Aboriginality in official cultural policy, by the 1980s, was generating among Indigenous public servants in Canberra a discourse on Aboriginality in which the facts of genealogy were less important than the social promptings of identity politics.

\section{Wayne King}

Wayne King, the author of Black Hours (1996) grew up about ten years ahead of Gordon Matthews, in Ipswich and in a working class Aboriginal family tormented by the father's alcohol problems. Upon leaving school, Wayne became a clerk in the Queensland public service. Although he was conscious of the racist unfairness of Queensland society, Wayne was not attracted to political activism. Rather, he sought his escape by taking a job in Canberra as a telex operator in the Department of External Affairs in 1966. In Canberra, he also found it possible to form a homosexual relationship, to be 'camp', in the parlance of the day. In 1967, he and his boyfriend Garry moved to Sydney, and Wayne got a job with 
Mitsubishi. His friends in Sydney included activists in Federal Council of Aboriginal and Torres Strait Islanders. As the issues of Aboriginal rights became more prominent in Australian public life, so, too, did the racism of his and Garry's gay acquaintances become apparent. It was difficult to deal with their racism, because Wayne found that there was a difference between the easily assumed liberalism of conversation about Indigenous political issues and the subtle racism that remained so powerful in his social life that he and his Aboriginal friends could not even talk to each other about the shame that they felt in being Aboriginal. By 1970, Wayne had found that no milieu in Australia offered him escape from white racism.

He applied to join the United Nations as a conference typist and moved to New York. There it was no longer necessary to be Aboriginal. 'On the streets of New York I might have been from anywhere - South America, Greece, Italy - and the racism wasn't directed against me' (1996: 98). The UN enabled him to be 'a citizen of the world' (1996: 98). Wayne relished a Bangladesh posting, with its good pay and the opportunities that he made for learning that other international language, French. Yet, after returning to New York he felt discontented, and in 1975 he resigned and went back to Sydney. As soon as he arrived, he knew he had made a mistake, for to be back in Australia was to be an Aboriginal person once more. Taking a job as a court reporter, he heard the room go quiet when he answered his new work-mates' questions about where he was from; the subsequent conversations about 'the Aboriginal problem' were a disheartening reminder of white Australian complacency. He worked as hard as he could to save the fare that took him back to New York in March 1976. 'This time I wouldn't come back to Australia. I would never come back to Australia. I knew I didn't belong. I would be a gypsy for the rest of my life' (1996: 125).

Wayne King found New York and Ismailia (outside Cairo) — his next United Nations posting — to be truly cosmopolitan spaces; people from many countries and of many colours worked side by side and among these work-mates there was simply no category 'A boriginal' available to apply to him. He became friendly with the only gay work-mate, an Argentine called Alfredo, and they mixed with a group of gay diplomats whose social outings would always begin by a discussion about which language they would use that night.

In the richest sense of the word, Wayne's happiness in Egypt was the product of his 'deracination'. Over several years, he had thoroughly uprooted himself from a culture in which he and his kind were the object of racism. He lived in a world that was relatively autonomous from the person-defining processes of family and nation. One word that describes this semi-detached world is 'impersonal'; here was 'impersonality' in a benign form, the demands and opportunities of international bureaucracy and of gay sexuality combining to foster an ethos of personal liberty. 
This turned out to be not enough for Wayne King, and his story makes it impossible to romanticise 'deracination'; he makes us see the limitations, for him, of the UN's cosmopolitan impersonality. He became alcoholic and psychotic, and this prompted him to come back to Australia and to hear his mother's life history. Black Hours is one of those Indigenous autobiographies - the most famous is Sally Morgan's My Place (1987) - in which the narrator discovers a part of the truth of him or herself in the narrative of a parent's or grandparent's suffering. As he puts it, 'I came back to Australia to find my roots. But I found my roots had been taken from me' (1996: 224). In that low state, a friend persuades him to join Alcoholics Anonymous, and the book ends with Wayne urging that Australians take a step towards national maturity by ceasing to deny their collective racism.

\section{Concluding Comments}

In each of these autobiographies, an Aboriginal man is enabled to see himself in new ways partly by his experience of being a public servant. There is a way to think about the impersonality of bureaucracy that assumes that impersonality is the nemesis of 'personality', as if the 'machine' necessarily tends to obliterate the person. Charles Perkins' account comes closest to saying something like this. Becoming a 'paper warrior' confines him; and he is impatient, and even dismissive, of the established procedures of financial administration and recruitment. Yet his attitude to 'impersonality' is on the whole more complex and ambivalent. When he reproaches the diplomats who failed to help him, he invokes an ethic of selfless pubic service, and he is in no doubt that Aborigines must learn to use the machinery of government, whether it be a Department of Aboriginal Affairs reconstituted as a statutory authority or their own publicly subsidised organisations. He joined the public service to learn its techniques, and as readers we know that he had thirteen years as a senior public servant after publishing his account of his initiation.

Gordon Matthews narrates his personal quest for the truth of his heritage partly according to the trope that impersonality is the nemesis of personality; I am thinking of his reluctance to reveal to his boss his discovery that he is in fact Sri Lankan-Australian, not Aboriginal-Australian, as if the machine would judge him as dishonouring its investment in him as an Aborigine. But his public service boss is not troubled by having quietly to change a line in Gordon's personal file. Not only did impersonal administration allow him to be 'Aboriginal' and even to reward him for being so; it was no less forgiving of his ceasing to be 'Aboriginal'. Bureaucratic impersonality turns out to be accommodating of 'difference'; it can choose to inscribe and re-inscribe ethnicity as merely the private characteristic of a functional person.

Finally, Wayne King allows us to see one of the limits of this accommodating impersonality. There is something enabling and something disabling about an 
ethos that does not care who you are. In the world of the floating UN bureaucrat, especially in that version of its socialities that gay men are able to perform, to be deracinated is both emancipating and deeply unsatisfying, at least for someone such as Wayne King who is in a condition of existentially insecure flight from the roots of his social being.

These three books give us a glimpse of the potential of administrative memoirs to be essays in the psychology of contemporary Australian liberalism. 